\title{
Hypertension, Asymmetric Renal Parenchymal Defect, Sterile Urine, and High E. coli Antibody Titre
}

\author{
H. J. ANDERSEN, B. JACOBSSON, H. LARSSON, J. WINBERG
}

British Medical fournal, 1973, 3, 14-18

\section{Summary}

During an 11-year period four children were seen with asymmetric renal parenchymal reduction, arterial hypertension, and sterile urine. The history and radiological or histological findings, or both, were consistent with "abacterial pyelonephritis" induced by bacterial infection in early childhood. All four had raised antibody titres to Escherichia coli. Three possibilities may explain the high antibody titres and insidious course of the renal damage-the presence of bacterial variants or amorphous bacterial antigen in the kidneys or the fact that because of cross-reactivity between certain $E$. coli $O$ antigens and renal tissue the " $E$. coli antibodies" were, in fact, autoantibodies.

\section{Introduction}

Progressive renal scarring accompanied by hypertension or renal insufficiency, sometimes labelled "active chronic pyelonephritis," often develops insidiously without evidence of bacterial infection (Longcope and Winkenwerder, 1933; Platt and Dawson, 1950; Saphir and Taylor, 1952; Kleeman et al., 1960; Kimmelstiel et al., 1961; Freedman, 1967; Penn and Breidahl, 1967; Angell et al., 1968; McGovern and Marshall, 1969). The aetiology is obscure in many instances and the role of infection has been questioned (Freedman, 1967; Angell et al., 1968). Several observations suggest, however, that bacteria may play a part in the initiation of the disease process (MacGregor, 1970).

We present here the results of Escherichia coli antibody determinations in four patients with hypertension, asymmetric reduction of the renal parenchyma, and sterile urine. The findings lend support to the relevance of initial bacterial infection in the evolution of the disease process.

\section{Patients and Methods}

From 1960 to 1966600 patients below the age of 16 years were admitted to hospital with an apparent first urinary tract infection not complicated by obstruction. During the same period five patients $(0.8 \%)$ were seen with unequivocal arterial hypertension and the radiological signs of chronic pyelonephritis as defined by Hodson (1965). Three of these patients had uninfected urine. This paper is concerned with these three patients and with a fourth with similar findings who was seen in 1971. There was no evidence of primary cardiac disease, glomerulonephritis, obstru-

University of Odense, Denmark

H. J. ANDERSEN, M.D., Associate Professor of Paediatrics

Children's Hospital, Göteborg, Sweden

B. JACOBSSON, M.D., Sous-chef of Paediatric $X$-ray Department

H. LARSSON, M.D., Head of Paediatric $X$-ray Department

University of Umeâ, Sweden

J. WINBERG, M.D., Professor of Paediatrics ctive uropathy, or renal artery malformation. One of the patients (case 1) was briefly reported on by Andersen (1968).

The $E$. coli antibody titre was examined by means of an indirect haemagglutination technique using crude $O$ antigen preparations as described earlier (Winberg et al., 1963). As the urine cultures were negative other antigen sources were usedeither $E$. coli from the patient's own faecal flora (cases 1 and 2) or a standard set-up of the eight $O$ antigens of the $E$. coli serogroups most commonly found in our patients with urinary tract infections (cases 1, 3, and 4) (Andersen, 1967; Winberg et al., 1967). These techniques were presented and discussed in earlier publications (Andersen et al., $1965 \mathrm{a}$; Andersen, 1968). A few serum specimens were titrated before and after treatment with 2-mercaptoethanol (Hanson and Winberg, 1967). The titres are given as reciprocals of half-dilution steps.

Clinical data on the four patients are summarized in tables I and II.

TABLE I-Clinical Findings on Admission

\begin{tabular}{|c|c|c|c|c|}
\hline $\begin{array}{l}\text { Case } \\
\text { No. }\end{array}$ & $\begin{array}{c}\text { Age on } \\
\text { Admission } \\
\text { (Years) }\end{array}$ & $\begin{array}{l}\text { Reason for } \\
\text { Admission }\end{array}$ & $\begin{array}{c}\text { Blood } \\
\text { Pressure } \\
(\mathrm{mm} \mathrm{Hg})\end{array}$ & $\begin{array}{l}\text { Evidence of Early Urinary } \\
\text { Infection }\end{array}$ \\
\hline 1 & 11 & Investigation & $180 / 125$ & Overt pyelonephritis at 2 years of \\
\hline 2 & 10 & $\begin{array}{l}\text { Visual dete- } \\
\text { rioration }\end{array}$ & $180 / 130$ & $\begin{array}{l}\text { Overt pyelonephritis at } 1 \text { year } \\
\text { and suspected at } 3 \text { years of age }\end{array}$ \\
\hline 3 & 13 & $\begin{array}{l}\text { Headache, } \\
\text { yomiting }\end{array}$ & $220 / 160$ & None \\
\hline 4 & 9 & $\begin{array}{l}\text { Generalized } \\
\text { convulsion }\end{array}$ & $210 / 150$ & $\begin{array}{l}\text { Overt pyelonephritis at } 5 \text { and } 7 \\
\text { years of age }\end{array}$ \\
\hline
\end{tabular}

TABLE II-Urinary Findings and Renal Function at Time of Admission

\begin{tabular}{|c|c|c|c|c|}
\hline $\begin{array}{l}\text { Case } \\
\text { No. }\end{array}$ & $\begin{array}{l}\text { Urinary } \\
\text { Cultures }\end{array}$ & $\begin{array}{c}\text { Urinary White } \\
\text { Cell Count }\end{array}$ & $\begin{array}{c}\text { Glomerular } \\
\text { Filtration } \\
\text { Rate }\end{array}$ & $\begin{array}{c}\text { Concentrating } \\
\text { Capacity }\end{array}$ \\
\hline $\begin{array}{l}1 \\
2 \\
3 \\
4\end{array}$ & $\begin{array}{l}\text { Negative } \\
\text { Negative } \\
\text { Negative } \\
\text { Negative }\end{array}$ & $\begin{array}{l}\text { Negative } \\
\text { Negative } \\
\text { Negative } \\
\text { Negative }\end{array}$ & $\begin{array}{l}\text { Normal } \\
\text { Normal } \\
\text { Low } \\
\text { Normal }\end{array}$ & $\begin{array}{l}\text { Low } \\
\text { Low } \\
\text { Low } \\
\text { Low }\end{array}$ \\
\hline
\end{tabular}

CASE 1

The patient, an 11-year-old boy, was admitted to hospital because of hypertension found on examination before tonsillectomy. Blood pressure $180 / 125 \mathrm{~mm} \mathrm{Hg}$. Ophthalmoscopy: hypertensive changes of grade II-III. Height -2 S.D. Urine analysis: traces of protein, no deposit. Urine cultures negative. Creatinine clearance normal (1801./ $\left.24 \mathrm{hr} / 1 \cdot 73 \mathrm{~m}^{2}\right)$, slightly reduced concentrating capacity (790 mOsm/1.). I.V.P.: bilateral caliceal dilatation and reduced parenchyma, more severe on the right (fig. 1). No dilatation of the renal pelvis or ureters. No vesicoureteral reflux on micturition.

Previous History.-A febrile urinary infection at the age of 2 years had been treated with sulphonamide with an uneventful course. At follow-up culture was negative. An I.V.P. on that occasion was normal (fig. 2). Urine specimens examined on several subsequent occasions in connexion with febrile illnesses showed nothing abnormal, but cultures were not performed.

CASE 2

This 10-year-old girl was admitted because of hypertension found on examination for an acute visual disturbance. Ophthalmoscopy showed 


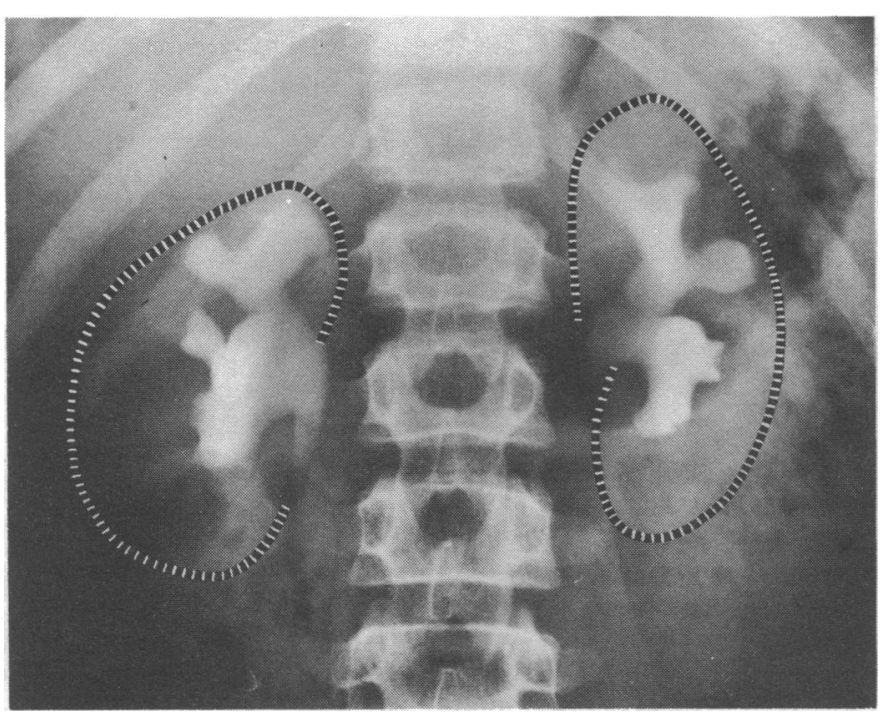

FIG. 1-Case 1. I.V.P. at time of detection of hypertension at 11 years of age.

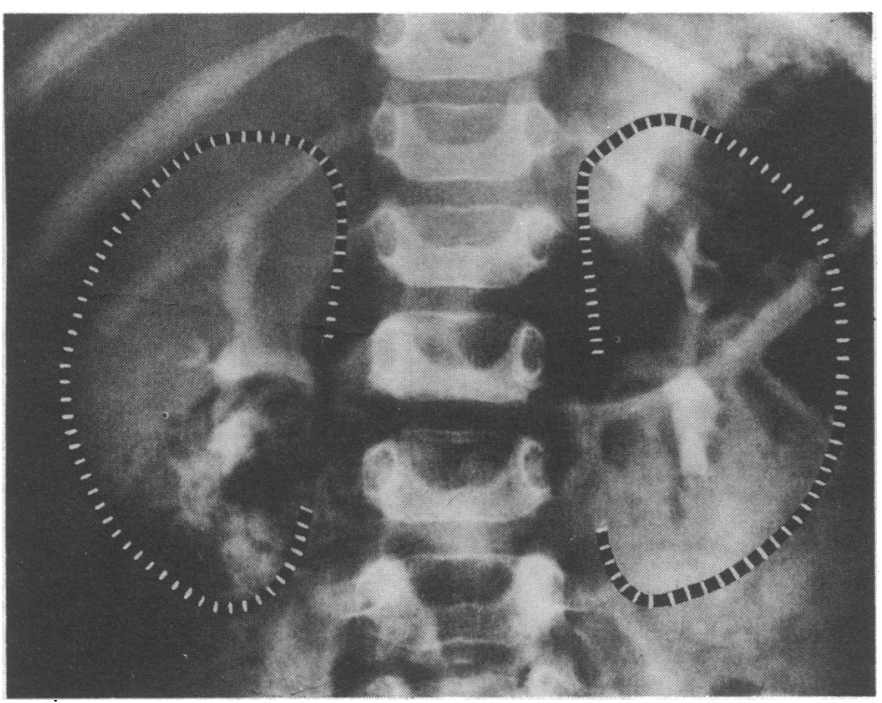

FIG. 2-Case 1. I.V.P. at time of patient's only observed urinary tract infection at 2 years of age.

a papillary protrusion of $3 \mathrm{D}$, narrow arteries, and small haemorrhages in the left fundus. The right eye was normal. An optic neuritis was suspected. Her general condition was good, with height and weight within normal limits. Blood pressure $180 / 130 \mathrm{~mm} \mathrm{Hg}$. Urine analysis: no protein, no cells, negative cultures. Creatinine clearance normal (130 1./24 hr/1.73 m²), reduced concentrating capacity (695 mOsm/1.). I.V.P.: no excretion on left side, slightly blunted calices on right (fig. 3). Bilateral reflux of grade II (Winberg et al., 1971). Renal angiography excluded renal artery stenosis. Left nephrectomy and sympathectomy was performed followed by treatment with antihypertensive drugs and sulphonamide for about a year, after which she was normotensive without drugs. Concentrating capacity one year after nephrectomy was $920 \mathrm{mOsm} / 1$.

The left kidney weighed $6 \mathrm{~g}$ and several flat scars were found on the surface. Microscopy showed hyalinized glomeruli, atrophic dilated tubules, interstitial fibrosis with round cell infiltration, and sclerosis of small arteries (fig. 4). In small, unscarified areas the glomeruli were well preserved. There was no dysplasia of the renal parenchyma. Fibrosis and inflammation was present in the pelvis.

Previous History. - At the age of 1 year a febrile $E$. coli urinary tract infection treated with sulphonamide was followed by an asymptomatic proteus infection. I.V.P. at the time of these infections showed nothing abnormal (fig. 5). At the age of 3 years the patient was treated

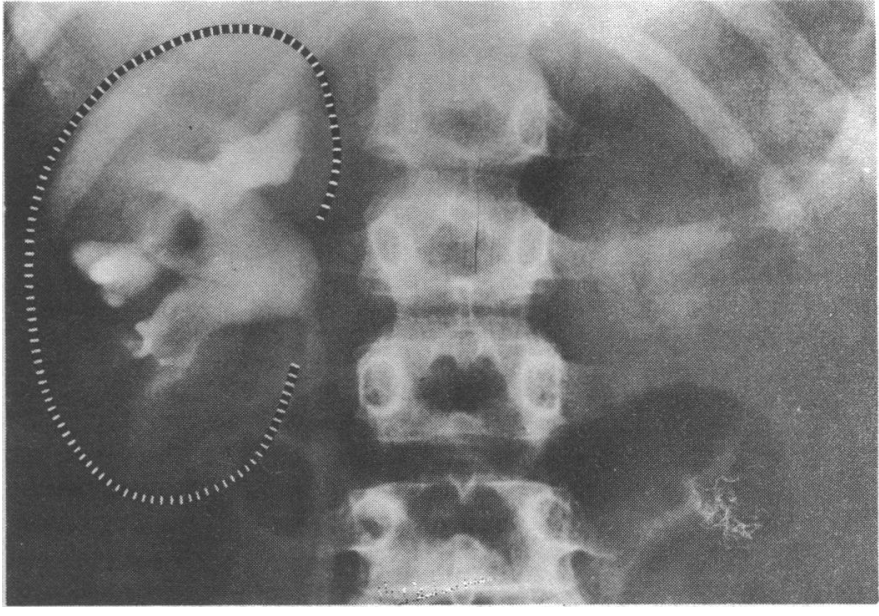

FIG. 3-Case 2. I.V.P. at time of detection of hypertension at 10 years of age No excretion on left side.

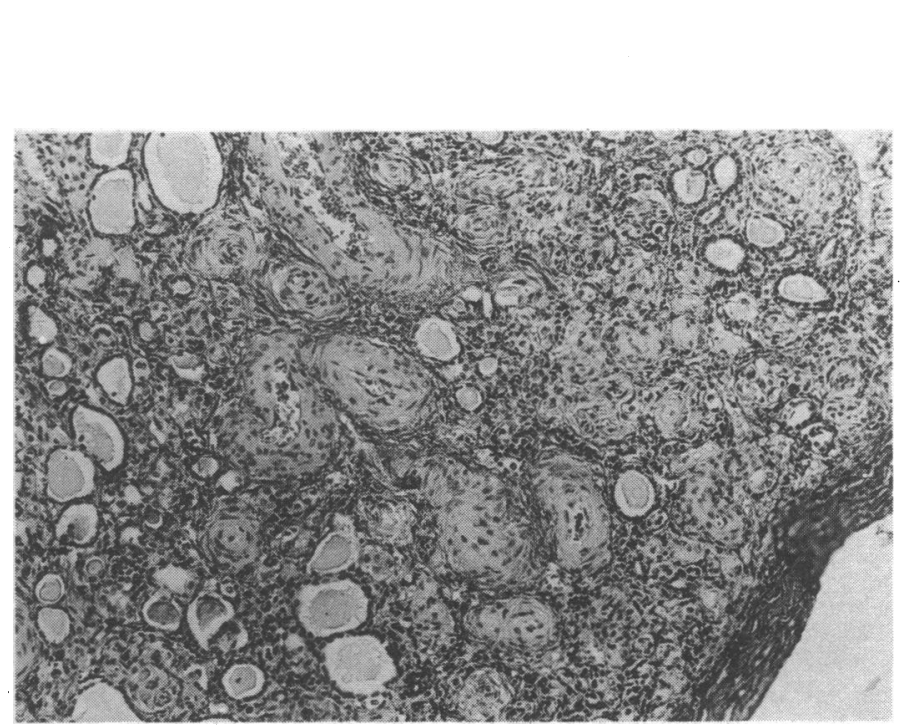

FIG. 4-Case 2. Histological specimen of left kidney after nephrectomy at age 10. For description see text.

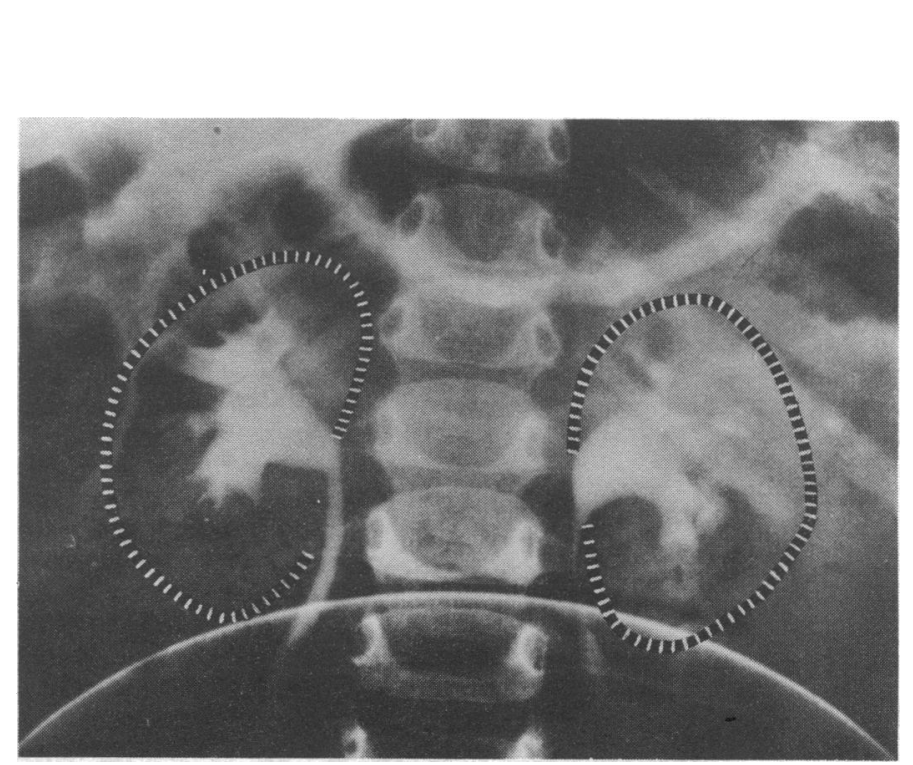

FIG. 5-Case 2. I.V.P. at time of first observed urinary tract infection at 1 year of age.

for a probable febrile urinary tract infection. Since then there had been no history of urinary infection. 
CASE 3

The patient, a 13-year-old girl, was admitted to hospital because of acute spells of headache and vomiting. Her general condition was good. Height and weight normal. Blood pressure 220/160 mm Hg. Ophthalmoscopy: hypertensive changes of grade IV. Urine analysis: no cells, negative cultures, protein $0 \cdot 3-2 \mathrm{~g} / 1$. (disappeared after antihypertensive treatment). Reduction in maximum renal concentrating capacity $(570 \mathrm{mOsm} / 1$.$) and clearance of inulin \left(38 \mathrm{ml} / \mathrm{min} / 1.73 \mathrm{~m}^{2}\right)$ and aminohippuric acid $(182 \mathrm{ml} / \mathrm{min} / 1.73 \mathrm{~m})$. Radiological examinations showed the renal papillae to be bilaterally flattened with corresponding parenchymal narrowing, more pronounced on the right (fig. 6). Bilateral reflux of grade II was noted. There was no renal artery stenosis.

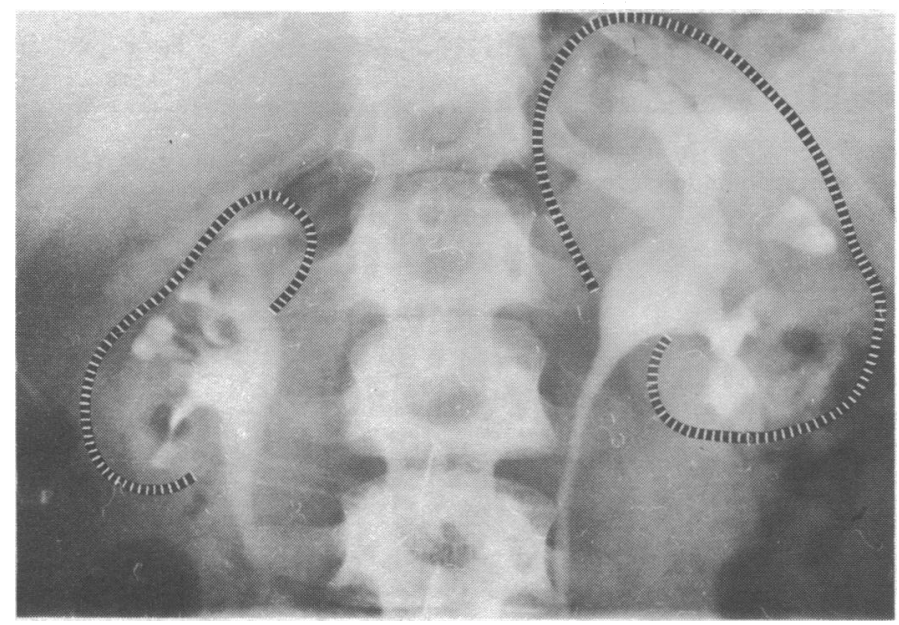

FIG. 6-Case 3. I.V.P. at time of detection of hypertension.

The blood pressure was reduced to about $125 / 95 \mathrm{~mm} \mathrm{Hg}$ with drugs and remained at that level. The concentrating capacity four years later was improved to $790 \mathrm{mOsm} / \mathrm{l}$. , while the clearance of inulin and aminohippuric acid was virtually unchanged. No progress of the parenchymal defects was found on I.V.P. seven years after the first admission. During the follow-up period several attacks of dysuria occurred. Urinary cultures were positive on at least one occasion.

Previous history was completely negative.

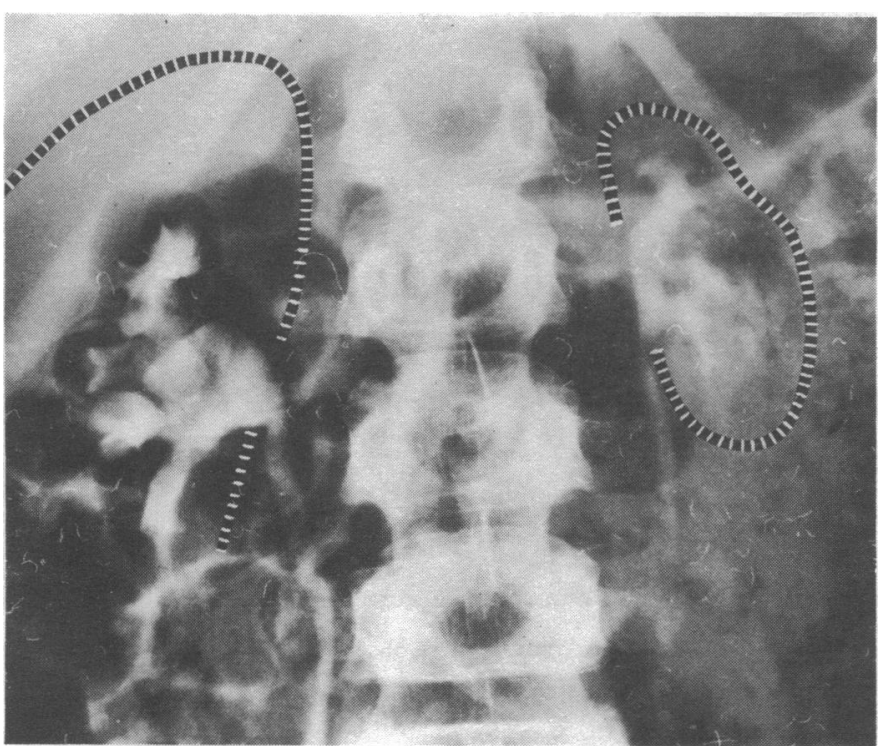

FIG. 7-Case 4. I.V.P. at time of detection of hypertension at 8 t years of age.
CASE 4

The patient, an 81 -year-old girl, was admitted to hospital because of generalized convulsions. Blood pressure $210 / 150 \mathrm{~mm} \mathrm{Hg}$. Weight and height within normal limits. Ophthalmoscopy: hypertensive fundi of grade II. Urine analysis: no cells, negative cultures, protein $1 \mathrm{~g} / 1$. Maximum renal concentrating capacity reduced (502 $\mathrm{mOsm} / 1$.), creatinine clearance normal $\left(1301 . / 24 \mathrm{hr} / 1.73 \mathrm{~m}^{2}\right)$. A radiorenogram gave normal findings on the right side, while the activity on the left side was about $20 \%$ of that on the right. An I.V.P. was normal on the right side but showed localized parenchymal defects with slightly flattened calices on the left (fig. 7). Reflux of grade III (Winberg et al., 1971) was present on the left side and grade II on the right. There was no renal artery stenosis. The renin activity in the right and left renal veins was 391 and $3,275 \mathrm{ng} / 100 \mathrm{ml} / 3 \mathrm{hr}$ respectively.

Nephrectomy combined with antihypertensive drugs led to normalization of the blood pressure. Six months after the operation the patient was normotensive without drugs. The left kidney weighed $20 \mathrm{~g}$. Deep scars were present on the surface. In large areas of the cortex almost all glomeruli were hyalinized and the tubules atrophic, partly with discrete cystic dilatation. Fibrosis and infiltration with round cells were seen in the interstitium. There were scattered areas of normal renal cortex. No dysplastic areas were observed. Round cell infiltration was present in the renal pelvis.

Previous History.-Two episodes of acute febrile urinary tract infection at the ages of 5 and 7 years had been treated with sulphonamide. Several urine cultures were done after treatment and all were negative.

\section{Results}

The results of the antibody determinations are illustrated in fig. 8. In case 1 titrations were performed separately with antigens derived from laboratory strains of $E$. coli $O$ groups $1,2,4,6,7,8,18$, and 75 . The antibody titres against $0-8$ antigen were greatly above normal, while the titres against the other $O$ antigens were 64 or less.

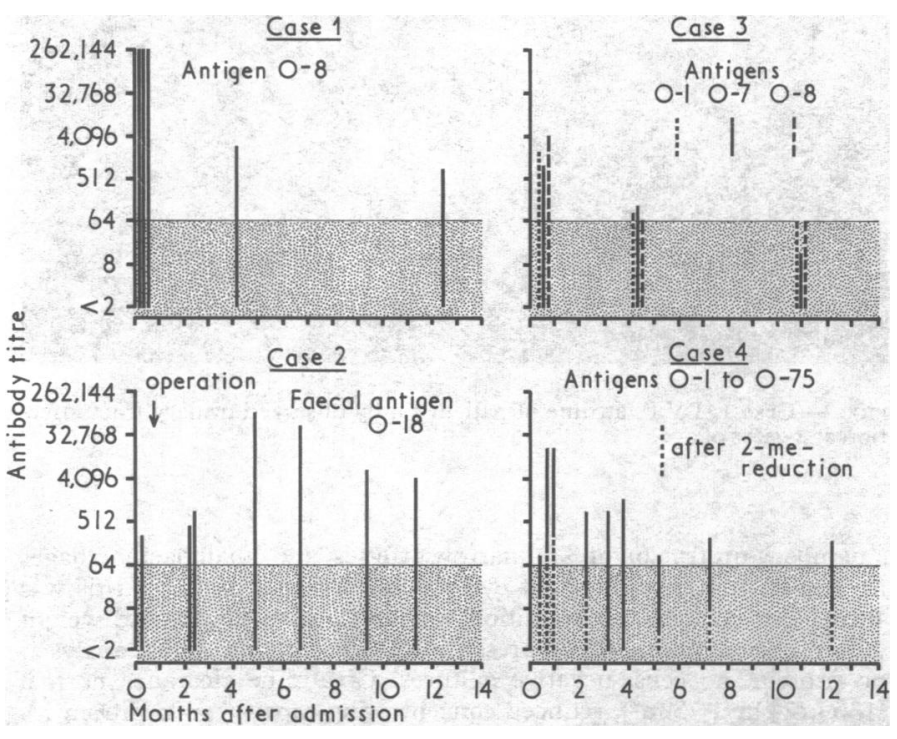

FIG. 8-E. coli antibody titres in the four patients with hypertension, asymmetric renal parenchymal defect, and sterile urine. Shaded area indicates range of $E$. coli antibody titres found in 116 controls (Andersen, 1968). 2 -me $=2$-mercaptoethanol.

In case 2 an antigen prepared from the patient's own faecal $E$. coli strains, later identified as $\mathrm{O}-18$, was used. The initial antibody titre was slightly raised. After the nephrectomy, however, a successive but long-lasting increase was observed, though the urinary cultures still were negative.

In case 3 the serum specimens were titrated separately against the standard panel of eight common $E$. coli $O$ antigens. Increased titres were found against $E$. coli $0-1,0-7$, and $0-8$ and normal titres were found against the other antigens. The 
titres decreased to normal during the following months at the same time as the blood pressure was controlled with antihypertensive therapy.

In case 4 an antigen pool of $O$ antigens $1,2,4,6,7,8,18$, and 75 was used (Andersen, 1967). Titrations were performed before and after reduction of serum with 2-mercaptoethanol. The titres were slightly raised on admission and rose rapidly after the nephrectomy, though repeated urine cultures were negative. The increase in antibody titre was followed by a successive decrease of titres in reduced as well as in nonreduced serum specimens. When serum was titrated against the individual components of the antigen pool the 0-8 and 0-75 antigens gave similar results to titration with the antigen pool, while the other components gave lower titres.

Different antigen sources were used in these patients because our methods for $E$. coli antibody determination were developed over a period of time (Winberg et al., 1963; Andersen et al., 1965 a; Andersen et al., 1965 b; Andersen, 1966; Andersen, 1967).

\section{Discussion}

Several factors lend support to the hypothesis that the renal parenchymal defects and the ensuing hypertension observed in these cases were caused by previous bacterial infections of the kidneys. Firstly, such infections were diagnosed several years earlier in three of the patients. Secondly, such radiological changes as asymmetric renal involvement, focal irregularities in the renal outline, and defects in the corresponding calices most probably result from infections, as suggested by comparative clinical, radiological, and morphological investigations (Smith, 1962; Hodson, 1965). It may sometimes be difficult to tell an infarct from a renal scar (Kincaid-Smith, 1955; Heptinstall, 1966). In these young children, however, there was no evidence of primary hypertension with secondary infarcts. In the two patients who were nephrectomized the morphological changes in the kidneys were consistent with postinfectious scarring as defined by Heptinstall (1966). There were no signs of dysplasia or of abnormalities of the vessels.

The fact that high antibody titres against some $E$. coli $\mathrm{O}$ antigens were found in all four patients with scarring, sterile urine, and hypertension who were admitted during the 11-year period suggests that the raised antibody titres were not incidental. The reduction sensitivity of the antibodies, shown in the one investigated case, suggests that the antibodies were at least partly of IgM type, implying presence of antigen continuously stimulating antibody formation (Uhr and Möller, 1968). The location and nature of this antigen is unproved, but in the absence of symptoms or a positive history from other organ systems it seems reasonable to assume that it was indeed present in the kidneys.

There are at least three possible mechanisms to explain the antibody formation-namely, the presence of bacterial variants (L-phase variants, protoplasts) in the kidneys; or the presence of amorphous bacterial antigen; or, finally, the third possibility would be cross-reactions between antibodies against $E$. coli antigen and renal tissue, which again would explain the raised titres.

Protoplasts have been found in kidneys of patients with sterile urine (Kalmanson and Guze, 1968; Turck et al., 1968), and injection of such variants into rat kidneys may produce localized fibrosis (Gutman et al., 1968). Kaijser et al. (1972) have shown that the variants contain sufficient antigen to induce and maintain antibody formation. The fact that the antibodies were directed against as many as three different $E$. coli $\mathrm{O}$ antigens would presuppose the simultaneous presence in the kidneys of variants belonging to up to three different serological types.

The second possibility is that amorphous bacterial antigen remained in the kidneys after previous infections and stimulated continuous antibody formation. Such antigen has been shown by immunofluorescent technique in tissue from the kidneys of patients with "abacterial pyelonephritis" (Aoki et al., 1969) and after cure of experimental pyelonephritis (Sanford et al., 1962; Cotran, 1963; Tan and Heptinstall, 1969). With specific antisera to $E$. coli $\mathrm{O}$ antigen on renal tissue from children nephrectomized because of pyelonephritic scarring $O$ antigen was shown in one out of 12 patients (Hanson, $1973 \mathrm{a}$ ).

The third possibility would be that because of the crossreactivity between antibodies directed against certain $E$. coli serotypes and antigen derived from renal tissue (Holmgren et al., 1971) the "E. coli" antibodies could, in fact, have been autoantibodies. So far such crossreactivity has been shown against only 0-2, 0-22, and 0-14 (Holmgren et al., 1971). It is, however, of interest that all three patients tested with the panel of eight different $E$. coli $O$ antigens $(1,2,4,6,7,8,18$, and 75 ) had antibodies against $0-8$. So far no antigenic relation between this antigen and kidney antigen has been shown (Hanson, $1973 \mathrm{~b}$ ). At the moment none of these three possibilities can be excluded as an explanation for the antibody production.

The cause of the rise in titre after the operation in cases 2 and 4 (fig. 8 ) is uncertain since urinary cultures were negative. One possibility is stimulation of antibody production due to antigen release during surgical manipulation of the kidneys.

The silent clinical course in many patients developing severe renal disease after bacterial infections (Longcope and Winkenwerder, 1933; Platt and Dawson, 1950; Kleeman et al., 1960; Kimmelstiel et al., 1961; Freedman, 1967; Penn and Breidahl, 1967; Angell et al., 1968; McGovern and Marshall, 1969; MacGregor, 1970), sometimes referred to as "pyelonephritis lenta" (Saphir and Taylor, 1952), makes it difficult to identify these patients among all others with a history of urinary tract infections early enough to prevent irreversible renal damage. The present investigation suggests that a long-lasting increase in the $E$. coli antibody titres may be a characteristic feature of progressive renal damage. In this context it is of interest that during long-term follow-up of antibody titres in patients with earlier acute pyelonephritis one was found to have persistently raised titres for several years in spite of negative urinary cultures. This patient had intermittently a moderately increased blood pressure (highest recorded 165/105 mm Hg). Three consecutive I.V.P.s showed non-progressive caliceal dilatation and reduction of the renal parenchyma of one of her kidneys (Andersen, 1968). The possibility of identifying potential "pyelonephritis lenta" cases by determination of $E$. coli antibodies should be further examined.

Whether the antibodies play any part in the pathogenesis of the renal damage is not known. One possibility, however, might be that complement-fixing antigen-antibody complexes are formed, causing renal damage in a similar way to that seen in poststreptococcal nephritis (Aoki et al., 1969; Hanson et al., 1971). The cross-reactions between antibodies directed against certain $E$. coli serotypes and renal tissue antigen mentioned above are another possible mechanism of renal damage but would be limited to infections with cross-reacting strains belonging to $O$ groups 2,14 , and 22 .

This investigation was supported by Swedish Medical Research Council grant No. 19x-765, and was carried out while Professors $H$. J. Anderson and J. Winberg were at the Department of Paediatrics, University of Göteborg, Sweden.

\section{References}

Andersen, H. J. (1966). Fournal of Pediatrics, 68, 542.

Andersen, H. J. (1967). Acta Paediatrica Scandinavica, 56, 637. Andersen, H. J. (1968). Acta Paediatrica Scandinavica, Suppl. No. 180. Andersen, H. J., Lincoln, K., Ørskov, F., Ørskov, I., and Winberg, J. (1965 a). Fournal of Pediatrics, 67, 1073.

Andersen, H. J., et al. (1965 b). Acta Paediatrica Scandinavica, 54, 247. Angell, M. E., Relman, A. S., and Robbins, S. L. (1968). New England Fournal of Medicine, 278, 1303.

Aoki, S., Imamura, S., Aoki, M., and McCabe, W. R. (1969). New England Fournal of Medicine, 281. 1375.

Cotran, R. S. (1963). Fournal of Experimental Medicine, 117, 813. 
Freedman, L. R. (1967). Annals of Internal Medicine, 66, 697

Gutman, L. T., Winterbauer, R. H., Turck, M., Wedgwood, R. J., and Petersdorf, R. G. (1968). In Microbial Protoplasts, Spheroplasts and $L$-forms, ed. L. B. Guze, p. 391 . Baltimore, Williams and Wilkins.

Hanson, L. A. (1973 a). Fournal of Infectious Diseases. In press.

Hanson, L. A. (1973 b). Personal communication.

Hanson, L. A., and Winberg, J. (1967). In Pyelonephritis, ed. H. Losse and M. Kienitz, p. 106. Stuttgart, Thieme.

Hanson, L. A., Holmgren, J., Jodal, U., and Winberg, J. (1969). Acto Paediatrica Scandinavica, 58, 506.

Hanson, L. A., et al. (1971). In Renal Infections and Renal Scarring, ed. P. Kincaid-Smith and K. Fairley. Melbourne, Mercedes.

Heptinstall, R. (1966). Pathology of the Kidney. Boston, Little, Brown and Co. Hodson, C. J. (1965). Proceedings of the Royal Society of Medicine, 58, 785.

Holmgren, J., Hanson, L. A., Holm, S. E., and Kaijser, B. (1971). International Archives of Allergy and Applied Immunology, 41, 463.

Kaijser, B., Brorson, J. E., and Seeberg, S. (1972). Acta Pathologica et Microbiologica Scandinavica, Section B, 80, 777.

Kalmanson, G. M., and Guze, L. B. (1968). In Microbial Protoplasts, Spheroplasts and L-forms, ed. L. B. Guze, p. 406. Baltimore, Williams and Wilkins.

Kimmelstiel, P., Kim, O. J., Beres, J. A., and Wellman, K. (1961). American Fournal of Medicine, 30, 589.

Kincaid-Smith, P. (1955). Lancet, 2, 1263.
Kleeman, C. R., Hewitt, W. L., and Guze, L. B. (1960). Medicine, 39, 3. Longcope, W. T., and Winkenwerder, W. L. (1933). Bulletin of the Fohns Hopkins Hospital, 53, 255.

McGovern, J. H., and Marshall, V. F. (1969). Fournal of Urology, 101, 668. MacGregor, M. (1970). Archives of Disease in Childhood, 45, 159.

Penn, I. A., and Breidahl, P. D. (1967). Australian and New Zealand Fournal of Surgery, 37, 163.

Platt, R., and Dawson, J. (1950). Quarterly fournal of Medicine, 19, 33.

Sanford, J. P., Hunter, B. W., and Donaldson, P. (1962). Fournal of Experimental Medicine, 116, 285.

Saphir, O., and Taylor, B. (1952). Annals of Internal Medicine, 36, 1017

Smith, J. F. (1962). Fournal of Clinical Pathology, 15, 522.

Tan, H. K., and Heptinstall, R. H. (1969). Laboratory Investigation, 20, 62.

Turck, M., Gutman, L. T., Wedgwood, R. J., and Petersdorf, R. G. (1968). In Microbial Protoplasts, Spheroplasts and L-forms, ed. L. B. Guze, p. 415. Baltimore, Williams and Wilkins.

$\mathrm{Uhr}$, J. W., and Möller, G. (1968). Advances in Immunology, 8, 81.

Winberg, J., Andersen, H. J., Hanson, L. A., and Lincoln, K. (1963). British Medical fournal, 2, 524.

Winberg, J., et al. (1967). Acta Paediatrica Scandinavica, Suppl. No. 177, p. 42

Winberg, J., Larsson, H., and Bergström, T. (1971). In Renal Infections and Renal Scarring, ed. P. Kincaid-Smith and K. Fairley. Melbourne, Mercedes.

\title{
Benzodiazepines and Tricyclic Antidepressant Plasma Levels
}

\author{
GERALD SILVERMAN, R. A. BRAITHWAITE
}

British Medical fournal, 1973, 3, 18-20

\section{Summary}

Twelve patients acted successfully as subjects to study what effect if any the benzodiazepines nitrazepam, diazepam, oxazepam, and chlordiazepoxide might have on steady-state plasma levels of nortriptyline and amitriptyline. No significant detectable effect was discovered. In view of the known interaction effects of other alternative tranquillizing drugs and hypnotics it seems reasonable to choose benzodiazepines wherever possible when anxiolytics or hypnotics need to be added during treatment of depression with tricyclic antidepressants.

\section{Introduction}

There is now a rapidly growing interest in drug interactions which may occur during psychiatric treatment. Particular attention has been paid to the way in which one drug may alter the plasma concentration of another, and much of the experimental results to date relate to plasma concentrations of tricyclic antidepressants. Depressive illness rarely presents without significant insomnia, and there is also commonly present anxiety and agitation. It is quite usual therefore for hypnotics and sedatives to be prescribed in addition to antidepressants. These additional drugs generally belong to one of three classes: barbiturates, phenothiazines, and benzodiazepines. Alexanderson et al. (1969) found that patients on nortriptyline who had also received a variety of barbiturates had lower steady-state plasma levels than their non-barbiturate

\footnotetext{
University Department of Psychiatry, Whiteley Wood Clinic, Sheffield S10 3TI

GERALD SILVERMAN, M.B., M.R.C.PSYCH., Lecturer in Psychiatry

Poisons Unit, Guy's Hospital, London SE1 9RT

R. A. BRAITHWAITE, A.R.I.C., Research Biochemist
}

controls. Hammer et al. (1967) found a fall of about half in the established steady-state plasma level of desipramine in a single subject when exposed to phenobarbitone. Burrows and Davies (1971) similarly found a dramatic fall in nortriptyline plasma level in a subject due to amylobarbitone. Barbiturates have for some time been known to be very potent inducers of hepatic microsomal enzymes in man (Conney, 1967, 1969; Prescott, 1971). These enzymes are responsible for the metabolism of many drugs, and it is as a result of their induction that barbiturates can effectively shorten the half lives of tricylcic antidepressants and thereby lower their plasma levels. Phenothiazines can exert the opposite effect. Gram and Over $\varnothing$ (1972) showed a reduced metabolism of imipramine and nortriptyline with concomitant perphenazine medication, presumably due to competition in the hepatic enzyme systems. Moody et al. (1967) found a considerable rise in plasma imipramine level with the addition of chlorpromazine in one subject. There is now evidence that the therapeutic efficacy of tricyclic antidepressants is related to plasma level. Asberg et al. (1971) obtained a curvilinear relation with reduced efficacy at both lower and higher plasma levels of nortriptyline. Braithwaite et al. (1972), for amitriptyline, found a simple positive linear correlation but Grüvstad (1973) has applied an alternative statistical analysis to their data and shown that it supports the curvilinear result of Åsberg. Burrows et al. (1972) and later work by KraghSørensen et al. (1973) do not show such clear relations however. Nevertheless it seems highly desirable to confine additional medication to drugs which do not substantially affect tricyclic antidepressant plasma levels during the treatment of depressed patients. The purpose of the present study was to discover what effect if any benzodiazepines might have on steady-state nortriptyline and amitriptyline plasma levels.

\section{Method}

Ideally, patients taking no other drugs than nortriptyline or amitripryline on a fixed oral dose were to be the subjects for the investigation. Achievement of steady-state plasma levels was assumed to have taken place when patients had been on the antidepressant for at least seven days. This is in accord with 